\title{
Analisis Tekno - Ekonomi Pemanfaatan Gas Suar Menjadi LPG di Lapangan XXX Kaltim
}

\author{
Safiqa Zulfa Nur Rochmi, Agus Wahyudi dan Akhmad Sofyan \\ Sekolah Tinggi Energi dan Mineral Akamigas, Cepu
}

\begin{abstract}
ABSTRAK
Tujuan pemanfaatan gas suar untuk Pengurangan import dan subsidi LPG. Secara garis besar terdapat 3 jenis infrastruktur pemanfaatan gas suar yang harus dikembangkan, yaitu Teknologi Gas Pre Treatment, Teknologi Ekstraksi LPG, dan Moda Distribusi CNG Skala Kecil. Lokasi Kilang LPG yang dipilih sekitar SPU - Anggana dengan pertimbangan dapat diakses oleh kendaraan pengangkut LPG dan CNG. Pemanfaatan gas suar menjadi LPG, memberikan keekonomian yang positif yaitu Dari Perusahaan Swasta, Biaya prasarana pemanfaatan gas suar dengan produk akhir gas kering dan LPG membutuhkan investasi prasarana berkisar Rp. 173 miliar. Kompresi dan perpipaan Rp. 30 miliar, kilang LPG Rp. 110 miliar serta fasilitas dan jaringan gas kering 0.5 mmscfd Rp. 33 miliar. Kelayakan bisnis memberikan NPV Rp. 16.0 miliar dan IRR 14.7\% pada saat 50\% investasi prasarana dipenuhi oleh APBN. Jangka waktu pengembalian modal swasta yaitu 5.2 tahun. Dari pemerintah, bantuan investasi pemerintah berupa prasarana ini mencapai Rp. 86.5 miliar, pemerintah juga berkewajiban menyiapkan tungku untuk rumah tangga dengan perkiraan investasi Rp. 20 miliar. Manfaat bagi pemerintah dari nilai jual gas suar, PPN produk gas kering, $\mathrm{PPh}$ korporasi dan penghematan subsidi LPG 3Kg mencapai Rp. 29 - 32 miliar per tahunnya. Sedangkan dari konsumen, untuk menaikkan keekonomian proyek, maka harga jual gas diasumsikan setara 90\% harga LPG existing ( Rp. 4,250), penghematan penggunaan bahan bakar LPG hanya separuh dari scenario sebelumnya yaitu sebesar Rp. 2,250/KK tiap bulannya. Apabila $1 \mathrm{mmscfd}$ dapat dimanfaatkan konsumen sebanyak 100,000 KK, maka penghematan mencapai Rp. 225 juta. Hal ini menandakan bahwa proyek pengembangan fasilitas pemanfaatan gas di Lapangan XXX memiliki probabilitas menguntungkan yang sangat tinggi dimasa mendatang.
\end{abstract}

Kata kunci: gas suar, LPG, keekonomian

\begin{abstract}
The purpose of the use of flare gas for Reduction of imports and subsidies of LPG. Broadly speaking, there are 3 types of flare gas utilization infrastructure that must be developed, namely Gas Pre Treatment Technology, LPG Extraction Technology, and Small Scale CNG Distribution Mode. Location of selected LPG Refinery around SPU - Anggana with consideration can be accessed by LPG and CNG carrier vehicles. The utilization of flare gas into LPG gives positive economy from Private Company. The cost of infrastructure of flaring gas utilization with end product of dry gas and LPG requires infrastructure investment around Rp. 173 billion. Compression and piping Rp. 30 billion, LPG refinery Rp. 110 billion and facilities and dry gas network 0.5 mmscfd Rp. 33 billion. Business feasibility gives NPV Rp. 16.0 billion and IRR $14.7 \%$ when 50\% of infrastructure investment is fulfilled by APBN. The payback period email: safiqa_zulfa@yahoo.com
\end{abstract}


is 5.2 years. From the government, the government's investment in infrastructure is $R p .86 .5$ billion, the government is also obliged to prepare a furnace for households with an estimated investment of Rp. 20 billion. The government benefits from the selling value of flare gas, dry gas PPN product, corporate income and subsidized $3 \mathrm{Kg}$ LPG subsidy reach Rp. 29 - 32 billion per year. Meanwhile, from the consumer, to increase the project's economy, the gas selling price is assumed to be equal to $90 \%$ of the existing LPG price ( $R p$ 4.250), the fuel consumption savings of LPG is only half of the previous scenario of $R p .2,250$ / KK per month. If $1 \mathrm{mmscfd}$ can be used by consumers as much as $100.000 \mathrm{KK}$, then the savings reach Rp. 225 million. This indicates that the development project of gas utilization facilities in XXX Field has a very high probability of future profits.

Key words: flare gas, LPG, economic

\section{PENDAHULUAN}

Peraturan Presiden Nomor 61 Tahun 2011 tanggal 20 September 2011 tentang Rencana Aksi Nasional Penurunan Emisi Gas Rumah Kaca, dimana pemerintah mendukung investasi untuk meningkatkan pemanfaatan gas bumi. Kebijakan Energi Nasional (KEN) menuju tahun 2050 yang telah disusun oleh Dewan Energi Nasional dan ditetapkan oleh Pemerintah melalui Peraturan Pemerintah No 79 Tahun 2014 tentang Kebijakan Energi Nasional (KEN) merupakan penjabaran dari UU No 30 Tahun 2007 tentang energy, yaitu asas kemanfaatan, rasionalitas, efisiensi berkeadilan, peningkatan nilai tambah, berkelanjutan, kesejahteraan masyarakat, pelestarian fungsi lingkungan hidup, ketahanan nasional, dan keterpaduan dengan mengutamakan kemampuan nasional. Indonesia memiliki banyak potensi gas alam.

Gas Suar (flare gas) adalah gas hidrokarbon yang dihasilkan oleh kegiatan eksplorasi dan produksi atau pengolahan minyak atau gas bumi yang dibakar karena tidak dapat ditangani oleh fasilitas produksi atau pengolahan yang tersedia sehingga belum termanfaatkan. Gas yang dibakar dapat berasal dari berbagai sumber, yaitu adanya kelebihan gas dari produsen yang tidak dapat dipasok ke konsumen, gas yang tidak terbakar pada fasilitas proses, adanya gangguan dari sistem proses, pergantian atau perawatan peralatan serta proses shutdown yang membutuhkan pembakaran sementara.

Pemanfaatan gas suar seringkali terkendala oleh volume gas yang relatif kecil dan menyebar, serta jauh dari infrastruktur pipa transmisi atau distribusi. Selain itu, belum adanya aturan baku yang memberikan dasar penetapan harga gas skala kecil, sehingga banyak pihak merasa khawatir dan keputusan baik untuk menyelamatkan sumber daya yang terbuang percuma bisa berujung menjadi temuan dan dianggap merugikan negara oleh para penegak hukum. Padahal gas suar tersebut masih mempunyai nilai untuk dimanfaatkan sebagai sumber energi sektor rumah tangga maupun pembangkitan skala kecil.

\section{METODE PENELITIAN}

Adapun metodologi kegiatan yang dilakukan pada tahun 2016 adalah sebagai berikut:

\section{A. Pengumpulan Data}

Dalam pelaksanaan kegiatan pengumpulan data ini perlu dilakukan Pendekatan Manajemen dan Pendekatan Teknis.

\section{Pendekatan Manajemen}

Pendekatan Manajemen dilakukan untuk mengendalikan dan mengkoordinasikan pekerjaan yang akan melibatkan tenaga ahli yang berpengalaman dari berbagai disiplin ilmu. Serta, diperlukan pendekatan kepada instansi terkait seperti Ditjen Migas KESDM, SKK Migas, BPH Migas, PT. Pertamina, Pemda Kalimantan Timur, dan Lembaga Litbang seperti LIPI (Lembaga Ilmu Pengetahuan Indonesia). 
Pendekatan Teknis

Pendekatan teknis berupa pengumpulan data dan referensi yang diperlukan dalam kegiatan ini. Pengumpulan data dapat dilakukan melalui survey langsung dan/atau data sekunder yang ada pada Lapangan XXX Kalimantan Timur.

\section{B. Analisis dan Evaluasi}

Data yang telah terkumpul selanjutnya dilakukan analisis dan evaluasi berdasarkan metode keteknikan dan keekonomian untuk menghasilkan suatu kajian kelayakan. Produksi gas dari Lapangan XXX berkisar 2 - 4 MMSCFD dan berupa gas associated. Untuk memastikan sisa cadangan dan pasokan gas secara continue maka kegiatan pertama yang akan dilakukan adalah studi bawah permukaan. Studi selanjutnya adalah analisis komposisi gas XXX untuk dijadikan masukan dalam proses seleksi teknologi pemanfaatan gas XXX. Proses seleksi teknologi terdiri dari design process (menggunakan software simulasi process) dan analisis keekonomian untuk menentukan teknologi mana yang paling optimal diterapkan pada Lapangan XXX dengan memasukan teknologi hasil litbang PPPTMGB "LEMIGAS" sebagai bagian dari teknologi pemanfaatan gas yang digunakan. Jenis teknologi pemanfaatan gas yang kemungkinan besar dapat diimplementasikan di Lapangan XXX sampai dengan pengguna akhir secara garis besar terdiri dari CNG, Mini LPG, Mini LNG dan Adsorbed Natural Gas.

Setelah terpilih teknologi pemanfaatan gas yang paling optimal untuk Lapangan XXX, dilakukanlah Front End Engineering Design (FEED) pada tahun 2017 untuk seluruh fasilitas pemanfaatan gas Lapangan XXX. Keluaran dari FEED adalah dokumen teknis dan dokumen harga penawaran sendiri (HPS) yang akan menjadi masukan dalam proses lelang (procurement) pada tahun berikutnya. Output dari kegiatan ini adalah:

- Kepastian cadangan gas

- Kelayakan teknis dari teknologi pemanfaatan gas di Lapangan XXX yang terintegrasi dengan teknologi hasil litbang LEMIGAS

- Kelayakan ekonomi

\section{HASIL PENELITIAN DAN PEMBAHASAN}

\section{A. Teknologi Pemanfaatan Gas}

Untuk memanfaatkan gas pada Lapangan XXX yang merupakan lapangan minyak dengan produk gas associated diperlukan pengembangan infrastruktur tertentu. Secara garis besar terdapat 3 jenis infrastruktur pemanfaatan gas yang harus dikembangkan, yaitu :

\section{- Teknologi Gas Pre-Treatment}

Gas associated yang dihasilkan oleh lapangan minyak biasanya memiliki kandungan impurities yang relatif tinggi; oleh sebab itu diperlukan unit gas treatment yang berfungsi memurnikan gas associated dari pengotor - pengotornya seperti $\mathrm{CO} 2, \mathrm{H} 2 \mathrm{~S}$, air, dan sebagainya. Secara umum unit pengolahan gas terdiri atas :

- Unit Separasi; fungsi utama unit ini adalah memisahkan gas bumi dari hidrokarbon berat lainnya. Alat utama pada unit ini adalah Separator yang akan memisahkan gas bumi dari hidrokarbon berat berdasarkan berat molekul.

- Unit Kompresi; fungsi dari unit ini adalah menyediakan tekanan yang diperlukan gas untuk melanjutkan proses pengolahan selanjutnya.

- Unit $\mathrm{CO}_{2}$ dan $\mathrm{H}_{2} \mathrm{~S}$ removal; fungsi dari unit ini adalah mereduksi impurities yang bersifat asam seperti $\mathrm{CO}_{2}, \mathrm{~N}_{2}$ dan $\mathrm{H}_{2} \mathrm{~S}$. Peralatan utama dari unit ini adalah sebuah kolom adsorbsi yang akan dialirkan adsorben untuk mengadsorb impurities - impurities yang ada pada gas. "LEMIGAS" memiliki produk inovasi pada unit ini berupa adsorben karbon aktif yang dapat digunakan untuk mengadsorbsi $\mathrm{H}_{2} \mathrm{~S}$. Untuk mereduksi $\mathrm{CO}_{2}$, "LEMIGAS" juga memiliki teknologi hasil riset dengan menggunakan $\mathrm{K}_{2} \mathrm{CO}_{3}$ (kalium karbonat) yang memiliki nilai keekonomian jauh lebih ekonomis dibandingkan dengan senyawa amine yang biasa dipakai pada umumnya

- Unit Dehidration (Dryer); fungsi dari unit ini adalah untuk mengurangi kandungan air dalam gas tersebut sehingga tidak terjadi proses pembekuan air dalam sistem 
perpipaan pada fasilitas pengolahan gas. Pada fasilitas ini "LEMIGAS" juga memiliki hasil riset teknologi yang bisa dimanfaatkan yaitu suatu unit dryer yang memanfaatkan karbon aktif sebagai penyerapannya.

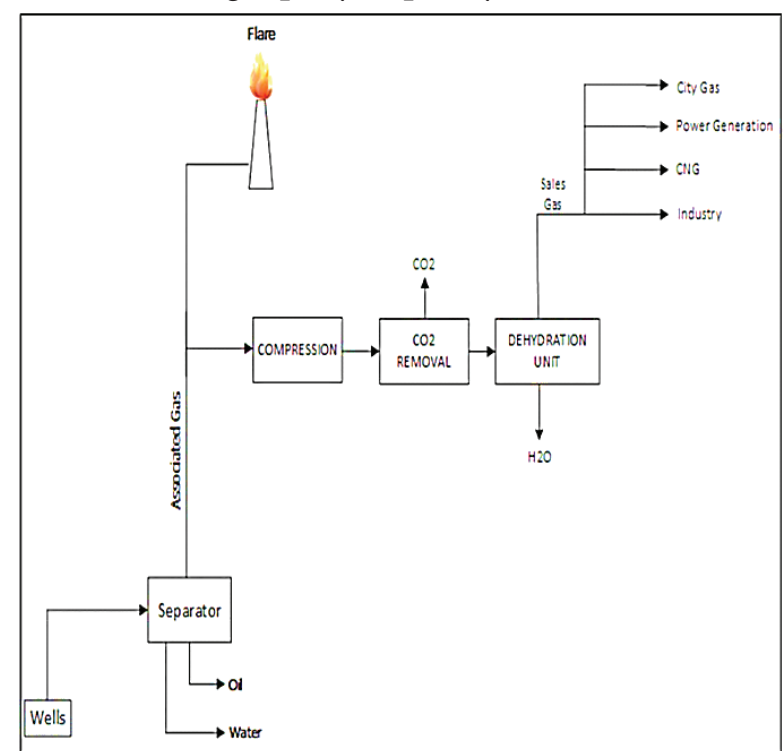

Gambar 1. Block diagram infrastruktur gas treatment untuk gas associated

\section{- Teknologi Ekstraksi LPG}

Pemilihan teknologi didasarkan pada kebutuhan dan efisiensi biaya. Untuk recovery LPG dari gas bumi tersedia beberapa pilihan proses antara lain dengan pendinginan menggunakan refrigerant (Propana atau ammonia).

Recovery LPG dengan pendingin propana adalah yang paling banyak digunakan untuk lapangan - lapangan gas skala kecil dan menengah. Beberapa contoh kilang LPG yang menggunakan pendingin Propana antara lain kilang LPG Cilamaya, Kilang LPG Cemara, Kilang LPG Tugu Barat, Kilang LPG Kaji, Kilang LPG Tambun, Kilang LPG SEP, Kilang LPG Titis Sampurna, dan Kilang LPG Tuban.

Recovery LPG dilakukan dengan menggunakan dua buah kolom fraksionasi yaitu kolom Deethanizer dan kolom Debuthanizer. Proses pendinginan dilakukan setelah dilakukan proses kompresi dan dehidrasi terlebih dahulu terhadap gas umpan. Gas selanjutnya didinginkan dengan menggunakan pendingin Propana. Liquid yang terbentuk dipisahkan dalam separator. Liquid yang keluar dari bagian bawah separator selanjutnya diumpankan ke kolom deethanizer untuk memisahkan fraksi etana dan yang lebih ringan. Produk bawah deethanizer berupa fraksi $\mathrm{C} 3+$ kemudian diumpankan ke kolom debuthanizer. Dalam kolom debuthanizer, fraksi LPG berupa propana dan butana dipisahkan dari fraksi berat berupa pentane plus.

\section{- Moda Distribusi CNG Skala Kecil}

Fasilitas sistem Mother Daughter terdiri atas 2 yaitu Fasilitas Mother Station dan Fasilitas Daughter Station. Fasilitas yang ada pada Mother Station antara lain:

- Compressor, digunakan untuk menaikan tekanan gas sampai 250 bar;

- Dryer, digunakan untuk memastikan kandungan air gas memenuhi spek;

- Storage, digunakan untuk penyimpanan sementara gas yang telah dikompress;

- Truck dispenser, digunakan untuk menyalurkan CNG ke truk pengangkut CNG atau CNG truck.

Daughter Station, terdiri atas fasilitas-fasilitas sebagai berikut:

- Storage, digunakan untuk menyimpan CNG yang didapat dari Mother Station;

- Regulator, digunakan pada konsumen industri atau pembangkit, umumnya berupa valve yang akan menyesuaikan tekanan gas yang dibutuhkan generator dari tekanan CNG;

- Distribution Dispenser, digunakan pada konsumen transportasi darat.

\section{B. Data dan Hasil Kegiatan}

Fasilitas produksi yang ada di Lapangan XXX adalah sebagai berikut:

- $\quad \mathrm{SP}-998$

SP - 998 terletak di wilayah paling utara dari area North Mahakam yang menerima fluida produksi dari 7 sumur produksi yaitu XXX - 981, XXX-995, XXX - 998, XXX - 1013, XXX - 1019, XXX - 1042 dan XXX-1053 dengan gross fluida terproduksi sebesar 5,100 barel dengan rata -rata WC 60\% sehingga produksi minyak net sekitar 2,000 bopd. Kontribusi produksi minyak terbesar 
adalah sumur XXX - 1013 yaitu 1,104 bopd (54\%) dengan mekanisme lifting menggunakan pompa ESP. Minyak hasil pemisahan selanjutnya dipompakan ke SPU Anggana melalui Trunk Line 6 inch sepanjang $4.5 \mathrm{~km}$. Fasilitas yang terdapat di SP - 998 masih sederhana terdiri dari Test Tank (8 unit), Storage Tank (7 unit), Transfer Pump (5 unit) dan Trukline 6 inch.

- $\quad \mathrm{SP}-\mathrm{XXX}$

SP-XXX terletak di area North Mahakam sekitar $4.5 \mathrm{~km}$ di Selatan SP-YYY yang menerima fluida gross dari 10 sumur produksi yaitu XXX 896, XXX - 950, XXX - 982, XXX - 1002, XXX - 1027, XXX - 1039, XXXL - 1040, XXX - 1041, XXX - 1051, dan XXX - 1049. Fluida terproduksi dari 10 sumur diperkirakan sebesar 4,500 barel dengan rata -rata WC 70\%, sedangkan produksi minyak sekitar 1,400 bopd. Kontribusi terbesar adalah sumur XXX - 1041 yaitu 706 bopd (50\%) yang masih mengandalkan natural flowing. Seperti halnya minyak dari SP - 998, maka minyak dari SP - XXX juga dipompakan menuju ke SPU Anggana melalui Trunk Line dengan diameter 8 inch. Fasilitas yang terdapat di SP XXX pun masih sederhana terdiri dari Test Tank (7 unit), Storage Tank (2 unit), Transfer Pump (5 unit) dan Trukline 8 inch.

\section{- $\quad$ SP - Site B}

SP - Site B terletak di area North Mahakam sekitar $4.9 \mathrm{~km}$ di Selatan SP- XXX yang menerima fluida gross dari 19 sumur produksi. Fluida terproduksi dari 19 sumur diperkirakan sebesar 12,800 barel dengan rata-rata WC $86 \%$, sedangkan produksi minyak sekitar 1,850 bopd. Hanya 3 sumur yang mampu memberikan produksi minyak berkisar 300 - 400 bopd. Minyak dari SP - Site B juga dipompakan menuju ke SPU Anggana melalui Trunk Line dengan diameter 8 inch. Fasilitas yang terdapat di SP - XXX pun masih sederhana terdiri atas Test Tank (13 unit), Storage Tank (4 unit), Transfer Pump (4 unit) dan
Trukline 8 inch. Dengan kecilnya produksi minyak dan gas associated dari SL - Site B, maka tidak dilakukan pengambilan sampel gas pada fasilitas tersebut.

\section{- $\quad$ SPU/PPP Anggana}

SPU/PPP Anggana terletak di area Anggana. SPU Anggana menerima fluida gross dari seluruh Stasiun Pengumpul (SP) di Area North Mahakam. Fasilitas produksi yang ada di SPU Anggana terdiri atas 2 buah FWKO, 2 buah Wash Tank, 4 buah Storage Tank, 3 buah Transfer Pump, 2 buah Loading Pump, 3 buah Boiler, serta 1 buah Gas Engine Genset.

\section{- $\quad \mathrm{SP}-\mathrm{Gas}$}

Disamping memproduksi minyak, Lapangan XXX juga terdapat sumur-sumur gas non associated. Beberapa sumur gas non - associated tersebut bargantian dan saling membackup untuk kebutuhan pembangkitan guna pemenuhan kebutuhan listrik operasi lapangan. Proses separasi gas untuk pembangkit listrik tersebut sangat sederhana yaitu manifold dan unit pemisahan separator dan scrubber, produk gas langsung digunakan untuk pembangkit listrik. Kebutuhan gasnon-associated untuk pembangkit listrik umumnya kurang dari 1 MMSCFD. Fasilitas produksi gas bumi di Lapangan XXX terdiri atas Separator, Scrubber, Dehydration Unit, dan Fuel Gas System.

\section{Analisis dan Hasil Evaluasi \\ - Subsurface}

Lapangan XXX juga menganalisa kedalaman reservoir dari Lapangan XXX, ketebalan reservoir dari Lapangan XXX , jenis batuan reservoir dari Lapangan XXX, porositas batuan dari Lapangan XXX, permeabilitas pada struktur XXX, karakteristik fluida dari Lapangan XXX, tekanan reservoir dari Lapangan XXX, gradient tekanan dari Lapangan XXX dan temperatur reservoir dari Lapangan XXX serta kandungan $\mathrm{CO}_{2}$ 
dari Lapangan XXX.

Reservoir di XXX sendiri berkarakter lenses, yaitu reservoir yang berlapis - lapis. Production zone pada reservoir XXX sebanyak 37 zone, dengan 42 zona perangkap reservoir. Tenaga pendorong untuk reservoir XXX adalah solution gas drive dan water drive. Reservoir XXX sendiri terdiri atas 3 blok, yaitu Blok AB, BF, dan FH.

\section{- Cadangan dan Produksi}

Cadangan awal minyak lapangan XXX adalah 153.822 MSTB, dengan RF total dari Lapangan XXX sebesar 29\% maka pengambilan maksimum yang diperoleh adalah 44.72 MSTB. Kumulatif produksi minyak akhir tahun 2014 dari Lapangan XXX yaitu 32.82 juta barel. Jumlah sumur pada lapangan tersebut yaitu 131 sumur dengan jumlah sumur produksi 36 sumur. Laju penurunan produksi minyak berkisar $26-86 \%$ per tahun. Produksi minyak saat ini berkisar $5,600 \mathrm{bbl} / \mathrm{d}$.

Tabel 1 Cadangan Minyak Lapangan XXX Kalimantan Timur

\begin{tabular}{|l|l|}
\hline OOIP & 153.82 MMSTB \\
\hline EUR & 44.72 MMSTB \\
\hline Recovery Factor Total & $29 \%$ \\
\hline Remaining Reserve & $\begin{array}{l}11.89 \text { MMSTB } \\
\text { (Status as of } 1 \text { January 2015) }\end{array}$ \\
\hline Cummulative Production & $\begin{array}{l}32.82 \text { MMSTB } \\
\text { (Status as of } 1 \text { January 2015) }\end{array}$ \\
\hline Recovery Factor Current & $21.9 \%$ \\
\hline
\end{tabular}

Cadangan awal gas pada Lapangan XXX sebesar 123.59 BSCF dengan RF total dari Lapangan XXX sebesar 57.4\% maka pengambilan maksimum gas adalah 71.02 BSCF. Cadangan tersebut termasuk didalamnya adalah gas associated dan non - associated.

Tabel 2 Cadangan Gas Lapangan XXX Kalimantan Timur

\begin{tabular}{|l|l|}
\hline OGIP & 123.59 BSCF \\
\hline EUR & 71.02 BSCF \\
\hline Recovery Factor Total & $57.4 \%$ \\
\hline Remaining Reserve & $\begin{array}{l}28.58 \text { BSCF } \\
\text { (Status as of 1 January 2015) }\end{array}$ \\
\hline Cummulative Production & $\begin{array}{l}42.44 \text { BSCF } \\
\text { (Status as of 1 January 2015) }\end{array}$ \\
\hline Recovery Factor Current & $34.4 \%$ \\
\hline
\end{tabular}

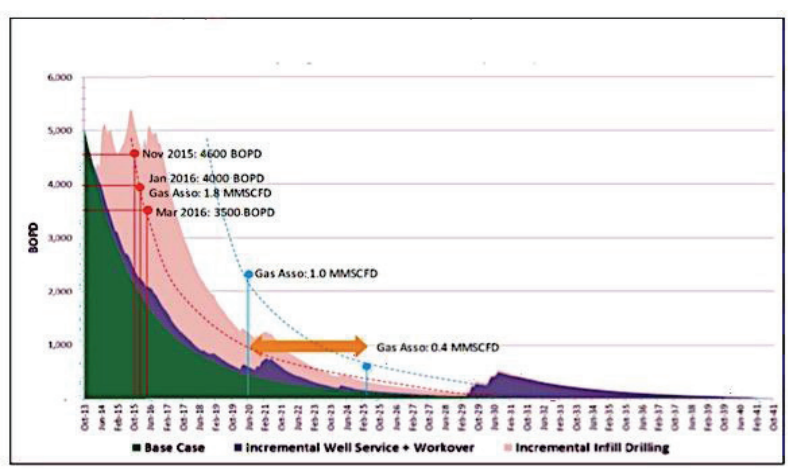

Gambar 2 Perkiraan Produksi Minyak dan Gas Associated Lapangan XXX 


\section{Komposisi Gas di Lapangan XXX}

Tabel 3 Hasil Analisa Kimia/Fisika dan Komposisi Gas Associated dan Non-Associated Lapangan XXX

\begin{tabular}{|c|c|c|c|c|c|c|c|c|c|}
\hline KODE SAMPEL & $:$ & 689.11Cilli2016 & 699.11, (1142016 & $70,9.116,112016$ & 71B.1K, & 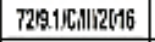 & $739.1 \mathrm{1C} \cap \mathrm{QQ016}$ & 748.15.11172016 & T3A.1С-1112016 \\
\hline CONPAYY & $:$ & NKLLPEP Asset 5 & NKL PEP Asset 5 & NKLL PEP Asse15 & NKL.PEP RES:T5 & NKLLPEP A5SAST & KKLL PEP Asset 5 & NIKL PEP ASSER 5 & NKLL PEP A 255 EA 5 \\
\hline LOKASI & $:$ & DutbetSeparator 983 & WellHead 1035 & Yiel Head 924 & BS NKL & HentHead & Outbu Seprabx992 & Well Head YSS & HallHead 997 \\
\hline TGL SAMPLING & $:$ & 2*Alar-16 & $2-Y_{a r}-16$ & $2+m a r \cdot 16$ & $3+h b r \cdot 16$ & $3+4 a r+16$ & 3Mar-16 & $3+\mathrm{ar}-16$ & 3 Hapras 15 \\
\hline נمN & $:$ & $15.00-1530 \mathrm{WTA}$ & $15.30-16.10$ \%ाA & 16.20-16.45 WTA & OA.3009.50 КTाA & $11.10-11.40 \mathrm{M} \Pi \mathrm{A}$ & 14.00 .1430 WTत & 14.30-14.50 MTA & 15.12.15.40 MTtA \\
\hline SUHU & $:$ & $108 \mathrm{~F}$ & & & $92 \mathrm{~F}$ & & $72 \mathrm{~F}$ & & \\
\hline TEKSNAN & : & Mpsig & 30) psigy & $1000 \mathrm{psig}$ & $25 \mathrm{psig}$ & $1100 \mathrm{psig}$ & $200 \mathrm{psig}$ & $62 \mathrm{psig}$ & 110 psisg \\
\hline CONPOUND & & $x_{M X}$ & X MOL & Snd & XYOL & SHOL & ${ }_{3}^{2} \mathrm{NOC}$ & SMOL & ¿ MOL \\
\hline Nitrogen & & 0.5762 & 0.3706 & 0.3208 & 0.2492 & 0.372 & 00388 & 0.0003 & 0.0442 \\
\hline Carbondioxide & & 2.7136 & 22901 & 79800 & 3.1523 & 10.4702 & 58255 & 4.1271 & 3.0480 \\
\hline Metane & & 67.0511 & 965290 & B4.6711 & 49.6981 & 16.1990 & 026474 & 8.2152 & $85.3 \mathrm{~s} 98$ \\
\hline Elane & & B.A373 & 0.0762 & $28 B 39$ & 12.4739 & 2.0243 & $6851 \%$ & 7.1200 & 6.5417 \\
\hline Propane & & 92069 & 0.0810 & 1.9837 & 16.3731 & 0.8910 & 26838 & 32992 & 29945 \\
\hline Iso Butane & & 35193 & 0.1064 & 0.3025 & 4.6919 & 0.1662 & 0.4621 & 0.6054 & 0.5464 \\
\hline N-Butane & & 4,1333 & 0,0000 & $0.37 \%$ & 6.1024 & 0.1977 & 0.545 & 0.7156 & 0.6579 \\
\hline Iso Pentane & & 19514 & 00099 & 0.1575 & 2.1759 & 0.0321 & $0.16 x$ & 02244 & 0.2181 \\
\hline N.Pentane & & 13347 & 0.0052 & 0.1230 & 1.0005 & 0.0646 & 0.135 & $0.169 ?$ & 0.1544 \\
\hline HexanePlus & & 28802 & 0.5295 & 1.5688 & 3.7408 & 0.4083 & 0.6314 & 03240 & 0.4509 \\
\hline Oxygen & & 0,0000 & 0.0000 & 0,0050 & 0.0000 & 0.0000 & 0,0000 & 0.000 & 0.0000 \\
\hline Relatf Density & & 0.9554 & 0.5967 & 0.7211 & 1.1311 & 0.6232 & 0.7071 & 0.6231 & 0.6506 \\
\hline HY Gross |BTUICFT) & & 1554.8766 & 10095680 & 1063.8699 & 10223467 & Sot.176t & 11013076 & 1129.3198 & 1129.1724 \\
\hline HVNET/BTUKFT| & & 1618.4420 & 909.8213 & 962.1978 & 1067.9475 & 8696450 & 90.662 & 1022.9936 & 1022.283 \\
\hline Compresibültasfaktor (A) & $: 1$ & 0.9934 & 0.9978 & 0.9962 & 0.9205 & 0.9974 & $0.996 \%$ & 0.9869 & 0.9970 \\
\hline
\end{tabular}

Untuk gas non - associated di Lapangan XXX, basis cadangan awal sebesar 23 BSCF dan perkiraan recovery factor sebesar 54\% sehingga maksimum pengambilan adalah 12.4 BSCF; yang berasal dari 22 sumur dan 22 layer. Gas non associated di Lapangan XXX memiliki plateau produksi sebesar 6 tahun, dengan rate produksi plateau 5 MMSCFD. Lifetime per sumur XXX sekitar 3 - 18 bulan bergantung pada cadangan yang dimiliki oleh setiap sumur dan treatment yang akan dilakukan. Gas yang dihasilkan dari sumur gas non -associated rencananya akan dikomersialisasi oleh PT. Pertamina EP Asset 5 untuk pemenuhan kebutuhan gas pembangkit listrik Tanjung Batu PT. PLN.
Tabel 4 Well Basis Non-Associated

\begin{tabular}{|l|l|}
\hline Cadangan well bassis & IGIP $=23$ BSCF \\
\cline { 2 - 2 } (workover 22 sumur, 22 layer) & EUR $=12.4$ BSCF \\
\cline { 2 - 2 } & $\mathrm{RF}=54 \%$ \\
\hline AOFP & $2-9$ MMSCFD \\
\hline Plateau Produksi & 6 tahun \\
\hline Rate Plateau & 5 MMSCFD \\
\hline Lifetime per sumur & 3-18 Bulan \\
\hline Avg. Ref Qgi & $0.5-1$ MMSCFD \\
\hline
\end{tabular}

- Pemanfaatan Gas Associated di Lapangan XXX

Komposisi metana dalam gas asosiasi tersebut hanya berkisar 50 - 67\% saja. Gas Asosiasi 
di Lapangan XXX dihasilkan dari tiga Stasiun Pengumpul (SP) Minyak yaitu SP - 998, SP XXX dan Site - B. Sebagian besar gas asosi tersebut dihasilkan dari SP - 998 dan SP - XX Gas asosiasi yang dihasilkan dari SP - 998 seki 1.2 MMscfd sedangkan dari SP -XXX sekitar 1 MMscfd.

Skenario Pemanfaatan Gas Associated

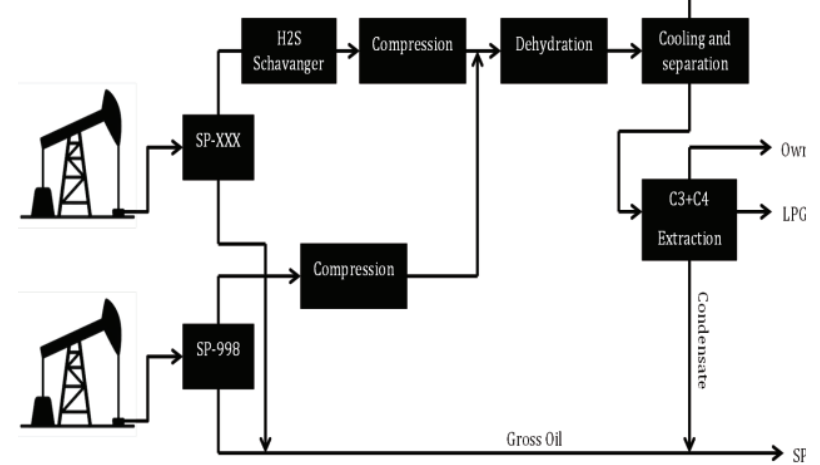

Gambar 3 Skenario Pemanfaatan Gas Associated

Gas yang keluar dari unit separasi merupakan gas bersih yang siap dikirim ke konsumen dalam bentuk CNG atau untuk kebutuhan internal PT Pertamina. Dari unit ekstraksi sendiri dihasilkan produk LPG mix, kondensat, dan gas. Gas yang keluar dari unit ekstraksi digunakan untuk kebutuhan bahan bakar kilang.

\section{- Lokasi Kilang LPG yang dipilih sekitar SPU Anggana}

Dari sisi biaya, penempatan Kilang LPG di sekitar SPU Anggana relatif lebih mahal karena membutuhkan jaringan pipa yang cukup panjang mencapai kurang lebih $18 \mathrm{~km}$. Selain memerlukan biaya pembangunan jaringan pipa yang cukup mahal, beban kompresor juga akan lebih tinggi. Namun demikian, akses kendaraan pengangkut LPG dan CNG serta mobilisasi peralatan lebih mudah karena lebih dekat dengan jalan umum. Tabel berikut memperlihatkan kelebihan dan kekurangan penempatan kilang LPG di sekitar SPU Anggana.
Tabel 5 Kelebihan dan Kekurangan Penempatan Kilang LPG di SPU Anggana

\begin{tabular}{|r|l|l|}
\hline No & \multicolumn{1}{|c|}{ Kelebihan } & \multicolumn{1}{c|}{ Kekurangan } \\
\hline 1 & $\begin{array}{l}\text { Jaringan pipa yang dibutuhkan lebih } \\
\text { panjang }\end{array}$ & $\begin{array}{l}\text { Akses jalan mudah dilalui } \\
\text { kendaraan pengangkut LPG } \\
\text { dan CNG }\end{array}$ \\
\hline 2 & $\begin{array}{l}\text { Diameter jaringan pipa yang } \\
\text { dibutuhkan lebih besar }\end{array}$ & $\begin{array}{l}\text { Mobilisasi peralatan relatif } \\
\text { lebih mudah }\end{array}$ \\
\hline 3 & beban kompresor lebih tinggi & \\
\hline
\end{tabular}

\section{- Desain Proses}

\section{a. Basic Design}

Kilang LPG akan didesain pada kapasitas 1 MMscfd sedangkan kapasitas operasi diperkiralaan berkisar 0,4 - 1 MMscfd selama kurang lebih 5: (lima) tahun sedangkan data komposisi dan liondisi operasi gas asosiasi sesuai pembahasan sebelumnya. Data pendukung adalah sebagai berikut;

a. Suhu udara

$\begin{array}{ll}\text { Minimum } & : 25 \mathrm{oC} \\ \text { Maksimum } & : 35 \mathrm{oC} \\ \text { Rata-rata } & : 30 \mathrm{oC}\end{array}$

b. Suhu tanah

Minimum : $25 \mathrm{oC}$

Maksimum : $35 \mathrm{oC}$

Rata - rata $: 30 \mathrm{oC}$

c. Kecepatan angin : $16 \mathrm{~km} / \mathrm{jam}$

Tabel 6 Spesifikasi Bahan Bakar Gas LPG untuk Keperluan Dalam Negeri sesuai Keputusan Dirjen Migas NO 25 K/36/DDJM/1990 Tanggal 14 Mei 1990

\begin{tabular}{|c|c|c|c|}
\hline 15S & DTiT? & Th? & CIITOD \\
\hline 5pesilic Gravity at $60 / 60^{\circ} \mathrm{F}$ & to be reported & to be reported & ASTM D-1657 \\
\hline Vapour Pressure $100^{\circ} \mathrm{F}$, psig & - & 120 & ASTM D-1267 \\
\hline Weathering Test $36^{\circ} \mathrm{F}, \% \mathrm{vol}$ & 95 & - & ASTM D-1837 \\
\hline Copper Corrosion $1 \mathrm{hr}, 100^{\circ} \mathrm{F}$ & - & No. 1 & ASTM D-1838 \\
\hline Total Sulfur. grains/ $100 \mathrm{cuft}$ & & 15 & ASTM D-2784 \\
\hline Water Content & No Free Water & No Free Water & Visual \\
\hline \multirow[t]{4}{*}{ Composition: } & & & ASTM D-2163 \\
\hline & - & 0.2 & \\
\hline & 97.5 & - & \\
\hline & - & 2.0 & \\
\hline Ethyl or Buthyl mercaptan added, ml/100 AC & 50 & 50 & \\
\hline
\end{tabular}




\section{b. Desain Proses Untuk Case Kilang LPG di SPU Anggana}

Pada case ini, gas asosiasi yang diproduksikan dari SP - 998 dikirim ke SP - XXX melalui jaringan pipa sepanjang $\pm 6 \mathrm{~km}$. Di SP - XXX, gas dari SP - 998 bergabung dengan gas asosiasi yang diproduksikan dari SP - XXX. Gabungan gas tersebut kemudian dikirim ke SPU Anggana sebagai lokasi kilang LPG melalui jaringan pipa sepanjang $\pm 14 \mathrm{~km}$.

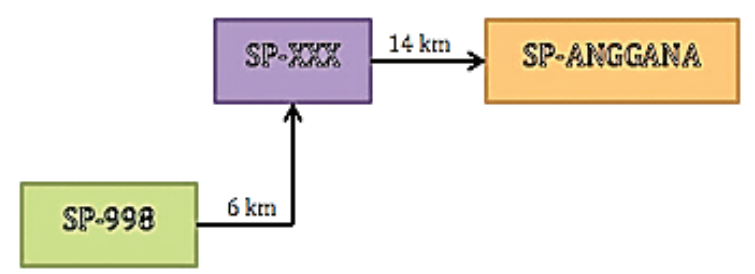

Gambar 4 Aliran Gas jika Kilang LPG ditempatkan di SPU Anggana

\section{c. Blok Diagram Process}

Gas asosiasi yang dihasilkan di SP - 998 dan SP - XXX memiliki tekanan yang relatif rendah yaitu 25 - 30 Psig sehingga dibutuhkan kompresor untuk mengalirkan gas tersebut ke lokasi kilang LPG yang berlokasi di sekitar SPU Anggana.

Gas asosiasi yang keluar dari separator di SP - 998 mula - mula dikompresi kemudian dialirkan ke SP - XXX melalui flowline sepanjang $6 \mathrm{~km}$. Gas dari SP - 998 tersebut selanjutnya bergabung dengan gas asosiasi dari SP -XXX yang sebelumnya telah dilewatkan ke unit H2S Schavanger dan dikompresi terlebih dahulu. Gabungan gas asosiasi tersebut selanjutnya dikirim ke kilang LPG yang ada di sekitar SPU Anggana melalui flowline sepanjang $14 \mathrm{~km}$. Gas yang tiba di fasilitas kilang LPG selanjutnya dikompresi kembali dan dialirkan ke Unit Dehidrasi guna mengurangi kadar air dalam aliran gas. Gas selanjutnya didinginkan dan hidrokarbon berat yang terkondesasi dipisahkan. Hidrokarbon berat yang keluar dari bagian bawah unit separasi dialirkan ke unit ekstraksi LPG sedangkan gas yang keluar dari bagian atas unit separasi merupakan gas bersih yang siap dikirim ke konsumen dalam bentuk CNG atau untuk kebutuhan internal PT Pertamina. Dari unit ekstraksi sendiri dihasilkan produk LPG mix, kondensat, dan gas.

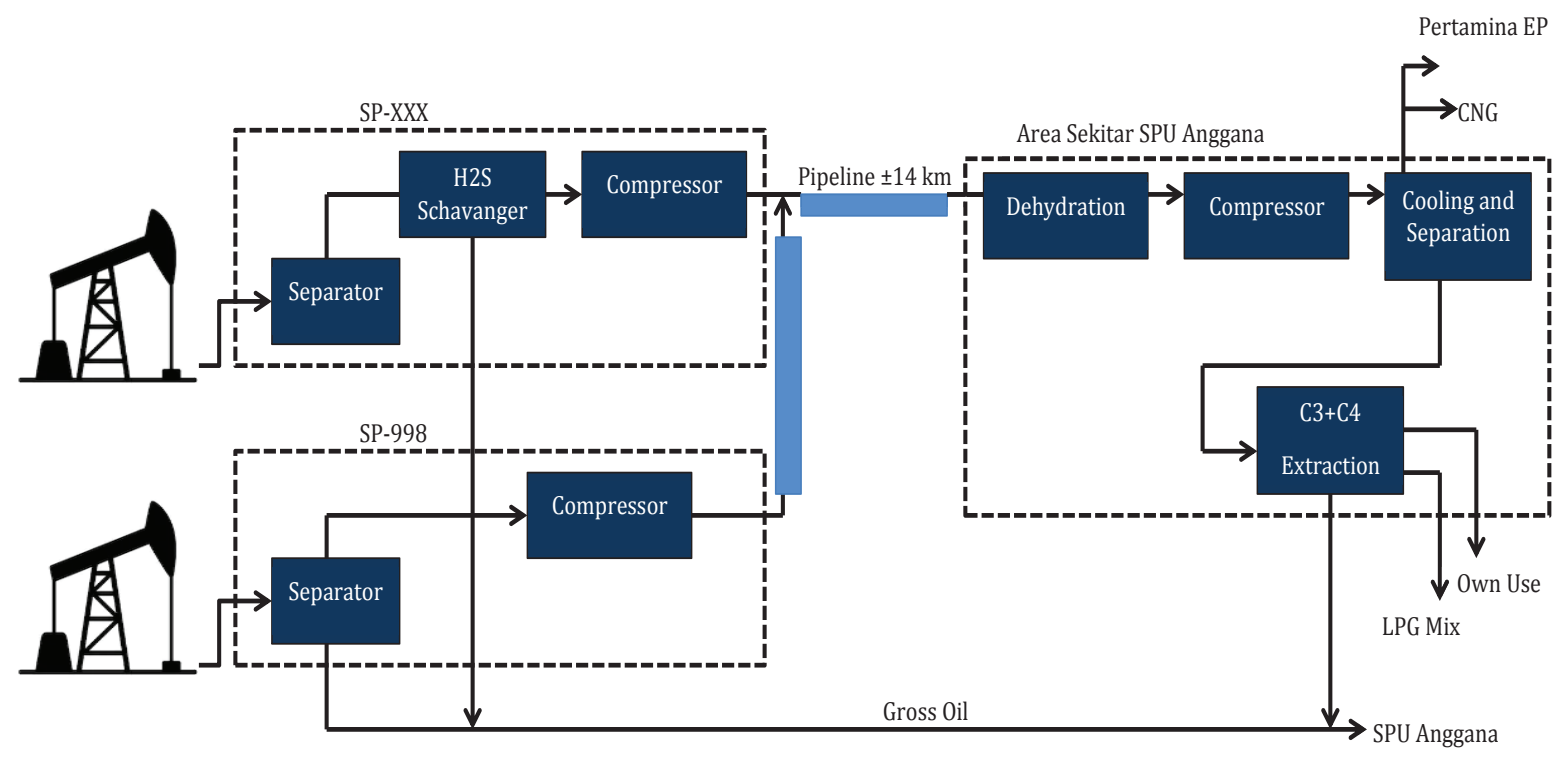

Gambar 5 Blok Diagram Proses Produksi di SPU Anggana 


\section{d. Pemilihan Teknologi}

Pemilihan teknologi didasarkan pada kebutuhan dan efisiensi biaya. Untuk recovery LPG dari gas bumi tersedia beberapa pilihan proses antara lain dengan pendinginan menggunakan refrigerant (propana atau ammonia), ekspansi dengan JT Valve atau Turbo Expander, atau kombinasi keduanya. Untuk gas umpan berkapasitas kecil dan memiliki tekanan relatif rendah, penggunaan refrigerant merupakan pilihan terbaik. Dalam studi ini dipilih propana sebagai refrigerant. Untuk unit dehidrasi menggunakan Molsieve karena sebagian lean gas akan digunakan untuk CNG.

\section{e. Process Flow Diagram}

Berdasarkan teknologi proses yang telah dipilih, selanjutnya dibuat diagram alir proses (Process Flow Diagram) dan simulasinya dari Kilang LPG yang akan dibangun. Diagram alir proses dan simulasinya tersebut terdiri atas tiga, yaitu diagram alir proses dan simulasinya di SP 998, SP - XXX dan SPU Anggana.

\section{f. Diagram Alir Proses dan Simulasi Proses di SPU Anggana}

Fasilitas proses yang ada di SPU Anggana berupa pemrosesan gas menjadi LPG terdiri atas separator, scrubber, kompresor, air cooler, dehydration unit, heat exchanger, separator, kolom fraksionasi, tangki LPG, flow meter, pompa dan CNG system.

Gas selanjutnya dialirkan ke discharge scrubber (V - 03C) untuk memisahkan cairan yang terkondensasi. Dari discharge scrubber, gas kemudian dialirkan ke Dehydration Unit (DHU - 01) untuk mengurangi kandungan air hingga maksimum 7 lb/MMscf. Gas yang keluar dari Dehydration Unit kemudian didinginkan oleh Heat Exchanger (E - 02C) dengan sebagai pendinginnya adalah gas yang keluar dari separator $(\mathrm{V}$ - 04C). Gas kemudian didinginkan oleh media Propana dalam Chiller (E - 03C). Gas yang telah didinginkan selanjutnya diekspansi dan dialirkan ke separator (V - 04C). Produk bawah separator digunakan sebagai media pendingin pada kondenser di kolom

Deethanizer ( $\mathrm{T}-01 \mathrm{C})$ dan kemudian diumpankan ke kolom tersebut. Produk atas kolom berupa gas digunakan sebagai bahan bakar internal (ownuse) sedangkan produk bawah berupa liquid dialirkan ke kolom Debutanizer ( $\mathrm{T}$ - 02C). Produk atas kolom Debutanizer merupakan LPG Mix yang selanjutnya dikirim ke tangki LPG (S -01C) sedangkan produk bawah kolom berupa kondensat dikirim ke Tangki Kondensat

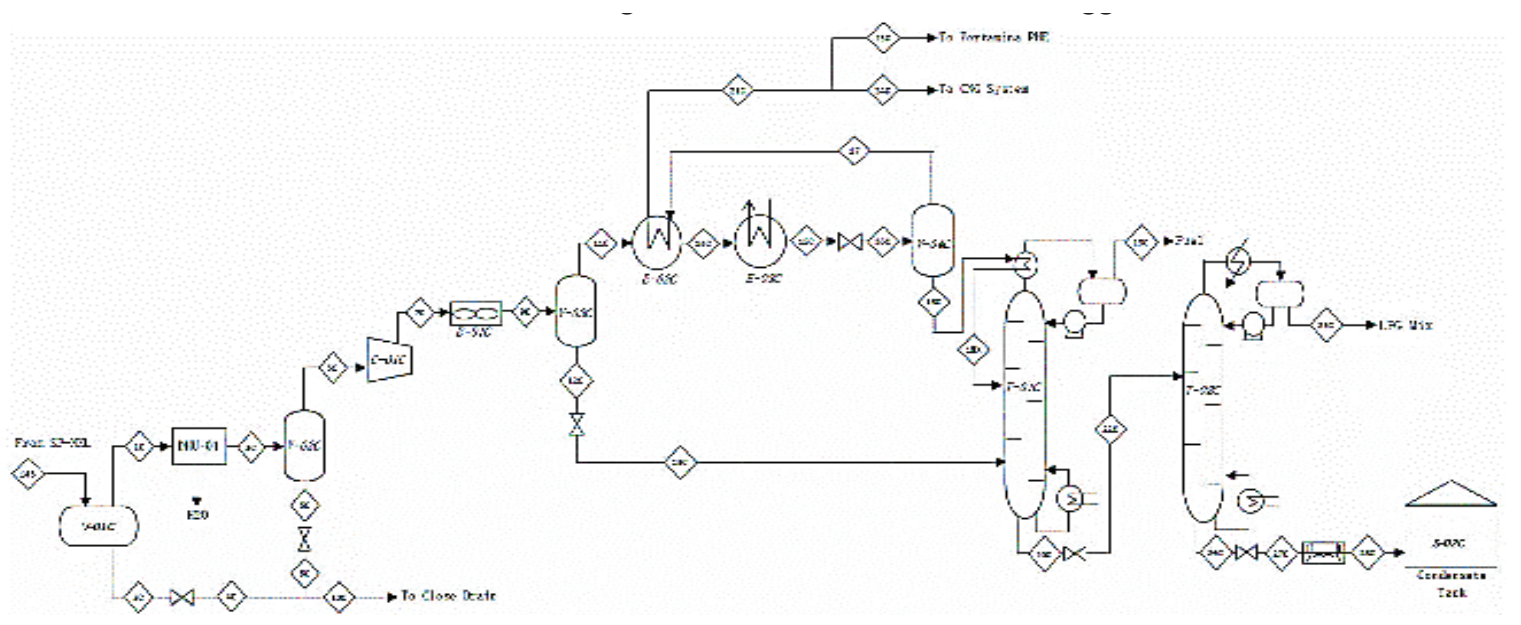

Gambar 6 Diagram Alir Proses Produksi LPG di SPU Anggana 
$(\mathrm{S}-02 \mathrm{C})$.

pendinginan dan pemisahan gas - kondensat,

Simulasi proses di SPU Anggana terdiri atas simulasi fasilitas penerimaan gas dari SP -

$\mathrm{XXX}$, rekompresi gas, proses dehidrasi, proses

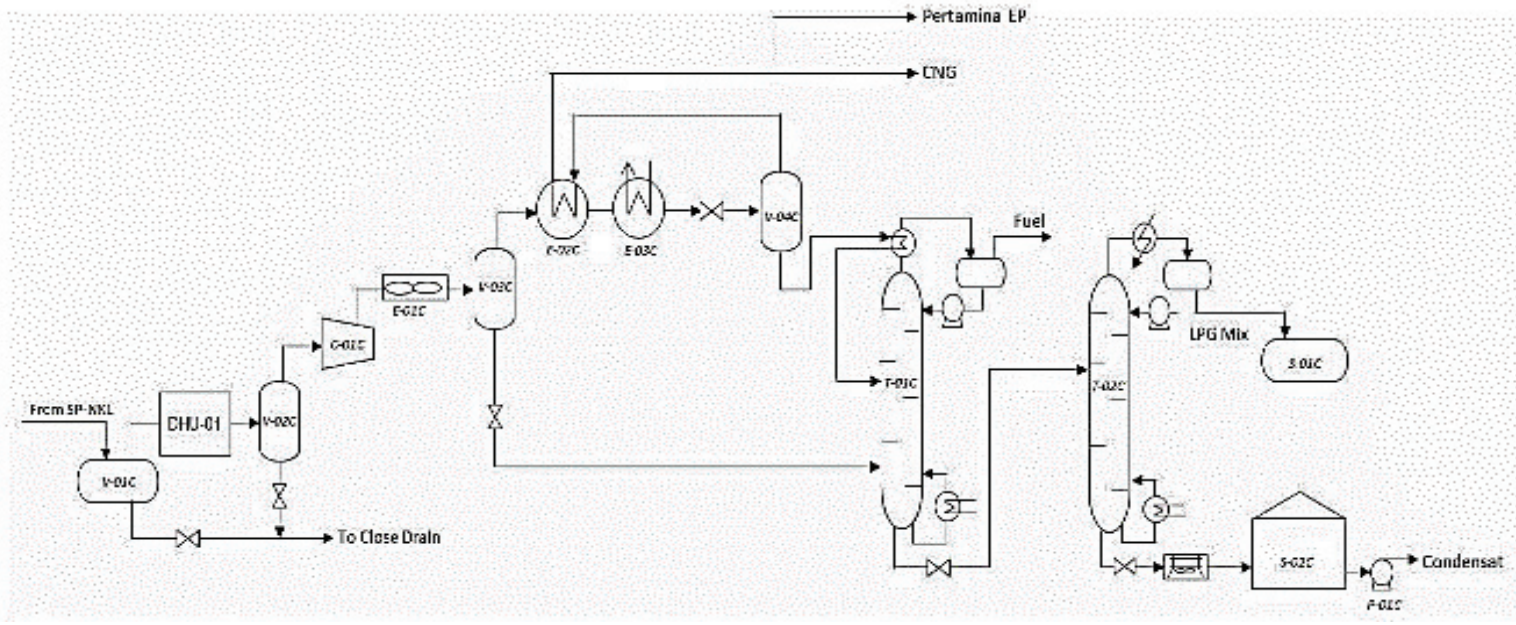

Gambar 7 Simulasi Proses Produksi LPG di SPU Anggana

Tabel 7 Neraca Massa Simulasi Proses Produksi LPG di SPU Anggana

\begin{tabular}{|c|c|c|c|c|c|c|c|c|c|c|c|c|c|c|c|}
\hline Name & $1 \mathrm{C}$ & $2 C$ & $3 C$ & $\mathbb{A C}$ & $5 C$ & $6 \mathrm{C}$ & 70 & BC & IC & $14 \mathrm{~B}$ & $10 \mathrm{C}$ & $11 \mathrm{C}$ & $12 \mathrm{C}$ & $13 \mathrm{C}$ & $14 \mathrm{C}$ \\
\hline Vapour Fraction & 1.00 &. & 1.00 & 0.18 & 1.00 &. & 1.00 & 0.22 & 0.99 & 0.98 & 0.18 & 1.00 & . & 0.13 & 0.81 \\
\hline Temperature (F) & 89.46 & 89.46 & 92.00 & 54.56 & 89.00 & 89.00 & 240.65 & 52.15 & 118.00 & 89.46 & 54.46 & 118.00 & 118.00 & 108.95 & 66.94 \\
\hline Pressure (psig] & 183.99 & 183.98 & 10.30 & 5.00 & 182.30 & 182.30 & 585.30 & 5.00 & 580.30 & 183.99 & 5.00 & 580,30 & 580,30 & 330.30 & 575.30 \\
\hline Molar Flow [MMSCFD] & 0.98 & 0.01 & . & 0.01 & 0.87 & 0.00 & 0.97 & 0.00 & 0.97 & 0.98 & 0.01 & 0.97 & 0.01 & 0.01 & 0.97 \\
\hline Nass Flow [Ton/d] & 29.35 & 0.36 & . & 0.36 & 29.27 & 0.01 & 29.27 & 0.01 & 29.27 & 29.71 & 0.37 & 28.64 & 0.62 & 0.62 & 28.64 \\
\hline Lliquid Volume Flow Ibarrelldayl] & 466.23 & 3.56 & . & 3.56 & 467.64 & 0.12 & 467.64 & 0.12 & 467,64 & 471.79 & 3.68 & 460.78 & 6.86 & 6.86 & 460.78 \\
\hline \multicolumn{16}{|l|}{ Composition ( $\mathrm{Mol}_{\mathrm{O}} \mathrm{\%}$ ) } \\
\hline $\mathrm{CO} 2$ & 3.21 & 0.40 & 3.22 & 0.40 & 3.22 & 0.52 & 3.22 & 0.52 & 3.22 & 3.19 & 0.40 & 3.24 & 1.25 & 1.25 & 3.24 \\
\hline Nitrogen & 0.79 & 0.01 & 0.79 & 0.01 & 0.78 & 0.02 & 0.79 & 0.02 & 0.79 & 0.78 & 0.01 & 0.79 & 0.07 & 0.07 & 0.78 \\
\hline Methane & 69.53 & 3.87 & 69.77 & 3.87 & 69.78 & 5.06 & 69.78 & 5.06 & 69.78 & 69.18 & 3.90 & 70.30 & 15.12 & 15.12 & 70.30 \\
\hline Ethane & 7.46 & 2.02 & 7.49 & 2.02 & 7.49 & 2.65 & 7.49 & 2.65 & 7.49 & 7.44 & 2.04 & 7.51 & 5.52 & 5.52 & 7.51 \\
\hline Propane & 9.69 & 8.52 & 9.72 & 8.52 & 9.72 & 11.20 & 0.72 & 11.20 & 9.72 & 9.68 & 8.59 & 9.65 & 17.61 & 17.61 & 9.65 \\
\hline LButane & 2.76 & 5.67 & 2.77 & 5.67 & 2.77 & 7.47 & 2.77 & 7.47 & 2.77 & 2.78 & 5.72 & 2.71 & 8.50 & 9.50 & 2.71 \\
\hline n-Butane & 3.47 & 9.80 & 3.48 & 9.80 & 3.48 & 12.81 & 3.48 & 12.91 & 3.48 & 3.51 & 8.88 & 3.37 & 15.14 & 15.14 & 3.37 \\
\hline I.Pentane & 1.20 & 7.88 & 1.20 & 7.88 & 1.20 & 10.38 & 1.20 & 10.38 & 1.20 & 1.23 & 7.94 & 1.12 & 9.67 & 9.67 & 1.12 \\
\hline n-Pentane & 0.81 & 6.96 & 0.82 & 6.96 & 0.82 & 0.18 & 0.82 & 9.18 & 0.82 & 0.85 & 7.02 & 0.75 & 7.87 & 7.87 & 0.75 \\
\hline n-Hexane & 0.47 & 11,63 & 0.47 & 11.63 & 0.47 & 15.32 & 0.47 & 15.32 & 0.47 & 0.53 & 11.73 & 0.38 & 8.17 & 0.17 & 0.38 \\
\hline n-Heptane & 0.24 & 16.34 & 0.24 & 16.34 & 0.23 & 21,38 & 0.23 & 21,38 & 0.23 & 0.32 & 16.47 & 0.16 & 8.22 & 8.22 & 0.16 \\
\hline n-Octane & 0.02 & 3.05 & 0.02 & 3.05 & 0.02 & 3.81 & 0.02 & 3.91 & 0.02 & 0.03 & 3.07 & 0.01 & 0.85 & 0.85 & 0.01 \\
\hline H2O & 0.36 & 23.85 & 0.01 & 23.85 & 0.01 & 0.00 & 0.01 & 0.00 & 0.01 & 0.48 | & 23.23 & 0.01 & 0.00 & 0.00 & 0.01 \\
\hline
\end{tabular}




\begin{tabular}{|c|c|c|c|c|c|c|c|c|c|c|c|c|c|c|c|}
\hline H2O & 0.36 & 23.85 & 0.01 & 23.85 & 0.01 & 0.00 & 0.01 & 0.00 & 0.01 & 0.48 & 23.23 & 0.01 & 0.00 & 0.00 & 0.01 \\
\hline Name & $15 \mathrm{C}$ & $16 \mathrm{C}$ & $17 \mathrm{C}$ & $18 \mathrm{C}$ & $18 x$ & $19 \mathrm{C}$ & $20 \mathrm{C}$ & $21 C$ & $22 \mathrm{C}$ & $23 \mathrm{C}$ & $24 C$ & $25 \mathrm{C}$ & $26 C$ & $27 \mathrm{C}$ & $28 \mathrm{C}$ \\
\hline Vapour Fraction & 0.65 & 0.70 & 1.00 & . & 0.27 & 1.00 & 0.00 & 1.00 & 0.43 & 1.00 & 1.00 & . & . & . & 0.06 \\
\hline Temperature $[\mathrm{F}]$ & $(38.00)$ & (57.91) & (57.21) & (57.21) & 38.00 & (12.93) & 204.58 & 110.00 & 134.33 & 110.00 & 110.00 & 102.47 & 270.10 & 118.00 & 104.47 \\
\hline Pressure [psig] & 570.30 & 335.30 & 335.30 & 335.30 & 330.30 & 325.30 & 335.30 & 330.30 & 125.00 & 330.30 & 330.30 & 120.00 & 130.00 & 127.00 & 0.30 \\
\hline Molar Flow [MMSCFD] & 0.97 & 0.97 & 0.68 & 0.28 & 0.28 & 0.13 & 0.16 & 0.68 & 0.16 & 0.10 & 0.58 & 0.14 & 0.02 & 0.02 & 0.02 \\
\hline Mass Flow [Ton/d] & 28.64 & 28.64 & 14.91 & 13.74 & 13.74 & 3.73 & 10.63 & 14.81 & 10.63 & 2.19 & 12.72 & 8.41 & 2.21 & 2.21 & 2.21 \\
\hline Llquild Volume Flow (barrellday] & 460.78 & 460.78 & 284.17 & 176.61 & 176.61 & 63.58 & 119.89 & 284.18 & 119.89 & 41.75 & 242.42 & 98.16 & 21.73 & 21.73 & 21.73 \\
\hline \multicolumn{16}{|l|}{ Composition (Yol \%) } \\
\hline $\mathrm{CO} 2$ & 3.24 & 3.24 & 3.17 & 3.40 & 3.40 & 7.48 & 0.00 & 3.17 & 0.00 & 3.17 & 3.17 & 0.00 & 0.00 & 0.00 & 0.00 \\
\hline Nitrogen & 0.78 & 0.78 & 1.10 & 0.07 & 0.07 & 0.15 & 0.00 & 1.10 & 0.00 & 1.10 & 1.10 & 0.00 & 0.00 & 0.00 & 0.00 \\
\hline Methane & 70.30 & 70.30 & 89.05 & 25.51 & 25.51 & 56.65 & 0.00 & 89.05 & 0.00 & 89.05 & 89.05 & 0.00 & 0.00 & 0.00 & 0.00 \\
\hline Ethane & 7.51 & 7.51 & 4.69 & 14.25 & 14.25 & 30.57 & 0.69 & 4.69 & 0.69 & 4.69 & 4.69 & 0.80 & 0.00 & 0.00 & 0.00 \\
\hline Propane & 9.65 & 9.65 & 1.69 & 28.66 & 28.66 & 5.06 & 46.93 & 1.69 & 46.93 & 1.69 & 1.69 & 54.95 & 0.00 & 0.00 & 0.00 \\
\hline l.Butane & 2.71 & 2.71 & 0.16 & 8.80 & 8.80 & 0.02 & 15.86 & 0.16 & 15.86 & 0.16 & 0.16 & 18.57 & 0.04 & 0.04 & 0.04 \\
\hline n-Butane & 3.37 & 3.37 & 0.12 & 11.14 & 11.14 & 0.01 & 20.28 & 0.12 & 20.28 & 0.12 & 0.12 & 23.67 & 0.46 & 0.46 & 0.46 \\
\hline I. Pentane & 1.12 & 1.12 & 0.01 & 3.77 & 3.77 & 0.00 & 7.12 & 0.01 & 7.12 & 0.01 & 0.01 & 1.75 & 38.51 & 38.51 & 38.51 \\
\hline n-Pentane & 0.75 & 0.75 & 0.01 & 2.52 & 2.52 & 0.00 & 4.85 & 0.01 & 4.85 & 0.01 & 0.01 & 0.25 & 31.74 & 31.74 & 31.74 \\
\hline n-Hexane & 0.38 & 0.38 & 0.00 & 1.30 & 1.30 & 0.00 & 2.79 & 0.00 & 2.79 & 0.00 & 0.00 & 0.00 & 19.09 & 19.09 & 19.09 \\
\hline n-Heptane & 0.16 & 0.16 & 0.00 & 0.53 & 0.53 & 0.00 & 1.39 & 0.00 & 1.39 & 0.00 & 0.00 & 0.00 & 2.53 & 8.53 & 9.53 \\
\hline n-Octane & 0.01 & 0.01 & 0.00 & 0.03 & 0.03 & 0.00 & 0.09 & 0.00 & 0.09 & 0.00 & 0.00 & 0.00 & 0.63 & 0.63 & 0.63 \\
\hline $\mathrm{H} 2 \mathrm{O}$ & 0.01 & 0.01 & 0.00 & 0.02 & 0.02 & 0.05 & 0.00 & 0.00 & 0.00 & 0.00 & 0.00 & 0.00 & 0.00 & 0.00 & 0.00 \\
\hline
\end{tabular}

\section{- Keekonomian}

\section{a. Estimasi Biaya Investasi Awal}

Biaya investasi awal yang dibutuhkan untuk membangun fasilitas pemanfaatan gas associated di Lapangan XXX adalah sebesar US\$ 8,636 juta. Sebesar $89 \%$ dari biaya investasi awal merupakan biaya investasi peralatan, sedangkan sisanya yang sebesar $11 \%$ merupakan working capital. Biaya investasi peralatan yang mencapai 7,515 juta US\$ secara garis besar terdiri atas 7 bagian yaitu:

Tabel 8 Estimasi Biaya Investasi Awal

\begin{tabular}{l|l|l}
\hline Unit Fasilitas & Komponen Fasilitas & \multicolumn{1}{|c}{ Biaya Investasi } \\
\hline \multirow{4}{*}{ Lapangan XXX } & Flow Line Pipe Unit & 635000 \\
\cline { 2 - 3 } & Compressor Unit & 3550000 \\
\cline { 2 - 3 } & Dehydration Unit & 61000 \\
\cline { 2 - 3 } & Fractionation Unit & 1250000 \\
\cline { 2 - 3 } & CNG Unit & 1016000 \\
\cline { 2 - 3 } & Utilities Unit & 1003000 \\
\hline
\end{tabular}

\section{b. Estimasi Biaya Operasional}

Biaya operasional tahunan yang diperlukan untuk menjalankan fasilitas pemanfaatan gas XXX adalah sebesar US\$ 683.433 per tahun. Secara umum biaya operasional tahunan fasilitas pemanfaatan gas XXX terdiri atas 3 jenis yaitu:

Tabel 9 Estimasi Biaya Operasional

\begin{tabular}{l|l|r}
\hline Unitfasilitas & \multicolumn{1}{|c|}{ Deskripsi Biaya } & \multicolumn{2}{|c}{ Biaya Investasi } \\
\hline \multirow{4}{*}{ Lapangan XXX } & Biaya Maintenance dan Asuransi & 192.1 \\
\cline { 2 - 3 } & Biaya Bahan Bakar & 125.6 \\
\cline { 2 - 3 } & Biaya Tidak Langsung & 365.6 \\
\hline & TOTAL & 683.4 \\
\hline
\end{tabular}

c. Hasil Perhitungan Keekonomian Pada Skenario Pemanfaatan Gas Suar untuk LPG

Perusahaan Swasta, biaya prasarana pemanfaatan gas suar dengan produk akhir gas kering dan LPG membutuhkan investasi prasarana berkisar Rp. 173 miliar. Kompresi dan perpipaan Rp. 30 miliar, kilang LPG Rp. 110 miliar dan fasilitas dan jaringan gas kering 
0.5 mmscfd Rp. 33 miliar. Kelayakan bisnis memberikan NPV Rp. 16.0 miliar dan IRR $14.7 \%$ pada saat $50 \%$ investasi prasarana dipenuhi oleh APBN. Jangka waktu pengembalian modal swasta yaitu 5.2 tahun.

- Pemerintah, bantuan investasi pemerintah berupa prasarana pada skenario ini mencapai Rp. 86.5 miliar, pemerintah juga berkewajiban menyiapkan tungku untuk rumah tangga dengan perkiraan investasi Rp. 20 miliar. Manfaat bagi pemerintah dari nilai jual gas suar, PPN produk gas kering, $\mathrm{PPh}$ korporasi dan penghematan subsidi LPG $3 \mathrm{~kg}$ mencapai Rp. 29 - 32 miliar per tahunnya.

- Konsumen, untuk menaikkan keekonomian proyek, maka harga jual gas diasumsikan setara 90\% harga LPG existing (Rp. 4,250), penghematan penggunaan bahan bakar LPG hanya separuh dari skenario sebelumnya yaitu sebesar Rp. 2,250 / KK tiap bulannya. Apabila $1 \mathrm{mmscfd}$ dapat dimanfaatkan konsumen sebanyak 100,000 KK, maka penghematan mencapai Rp. 225 juta.

Hal ini menandakan bahwa proyek pengembangan fasilitas pemanfaatan gas XXX merupakan proyek yang memiliki probabilitas menguntungkan yang sangat tinggi di masa mendatang.

\section{KESIMPULAN}

1. Lapangan XXX terletak di sebelah Utara Mahakam, Kalimantan Timur. Lapangan XXX merupakan salah satu struktur di Lapangan Sanga - sanga, Kalimantan Timur, yang saat ini dikelola oleh PT. Pertamina EP Asset 5. Lapangan Sanga - sanga sendiri berada \pm 50 KM sebelah Timur kota Samarinda, yang termasuk di dalam daerah cekungan Kutai yang memiliki potensi besar untuk cadangan gas alam. Mulai produksi minyak di Lapangan XXX pada tahun 1947 dengan kumulatif produksi minyak sampai 2013 sebesar 30.1 juta barel, jumlah sumur 131 sumur, 36 sumur produksi. Laju penurunan produksi minyak lapangan XXX $\pm 26-86 \%$ per tahun, produksi minyak saat ini $\pm 5600 \mathrm{bbl} / \mathrm{d}$ dengan menggunakan Artificial Lift, karena tekanan bawah sumur $<$ tekanan permukaan. Produksi Gas Associated \pm 1.8 MMscfd, SP - 998 sebesar 1.2 MMscfd dan SP - XXX sebesar 0.6 MMscfd. Terdapat 3 buah fasilitas produksi minyak bumi di Lapangan XXX (SP - 998, SP - XXX, dan SP - Site B), dan dikirim ke SPU - Anggana.

2. Pemanfaatan gas suar seringkali terkendala oleh volume gas yang relative kecil dan menyebar serta jauh dari infrastruktur pipa transmisi atau distribusi.

3. Faktor yang menjadi kendala dalam pemanfaatan gas suar adalah beragamnya komposisi dari gas suar itu sendiri.

4. Perbedaan komposisi dari gas suar akan mengakibatkatkan perbedaan teknologi pengolahan dan pemanfaatan akan yang digunakan, sehingga berpengaruh terhadap keekonomiannya juga.

5. Lokasi Kilang LPG yang dipilih untuk pemanfaatan gas suar menjadi produk LPG, sekitar SPU - Anggana dengan pertimbangan dapat diakses oleh kendaraan pengangkut LPG dan CNG.

6. Pemanfaatan gas suar menjadi produk LPG dan gas kering (gas pipa atau CNG), maupun kondensat memberikan keekonomian yang positif, meskipun jika dilaksanakan sepenuhnya oleh swasta belum dapat mencapai return yang wajar secara bisnis. Namun jika sebagian investasi dilakukan dengan pendanaan APBN, prospek kelayakan bisnisnya bisa terpenuhi.

7. Dari Perusahaan Swasta, Biaya prasarana pemanfaatan gas suar dengan produk akhir gas kering dan LPG membutuhkan investasi prasarana berkisar Rp. 173 miliar. Kompresi dan perpipaan Rp. 30 miliar, kilang LPG Rp. 110 miliar dan fasilitas dan jaringan gas kering 0.5 mmscfd Rp. 33 miliar. Kelayakan bisnis memberikan NPV Rp. 16.0 miliar dan IRR $14.7 \%$ pada saat $50 \%$ investasi prasarana dipenuhi oleh APBN. Jangka waktu pengembalian modal swasta yaitu 5.2 tahun.

8. Dari Pemerintah, bantuan investasi pemerintah berupa prasarana pada skenario ini mencapai Rp. 86.5 miliar, pemerintah juga 
berkewajiban menyiapkan tungku untuk rumah tangga dengan perkiraan investasi $\mathrm{Rp}$. 20 miliar. Manfaat bagi pemerintah dari nilai jual gas suar, PPN produk gas kering, PPh korporasi dan penghematan subsidi LPG 3 kg mencapai Rp. 29 - 32 miliar per tahunnya.

9. Dari Konsumen, untuk menaikkan keekonomian proyek, maka harga jual gas diasumsikan setara 90\% harga LPG existing (Rp. 4,250), penghematan penggunaan bahan bakar LPG hanya separuh dari skenario sebelumnya yaitu sebesar Rp. 2,250 / KK tiap bulannya. Apabila 1 mmscfd dapat dimanfaatkan konsumen sebanyak 100,000 KK, maka penghematan mencapai Rp. 225 juta.

\section{DAFTAR PUSTAKA}

Cheremisinoff, N.P. 2013. "Industrial Gas Flaring Practices". Wiley. New York.

Lubiantara, B. 2012. "Ekonomi Migas: Tinjauan Aspek Komersial Kontrak Migas". Gramedia Widiasarana Indonesia.

Kementerian Energi dan Sumber Daya Mineral. 2015. "Handbook of Energy and Economic Statistics of Indonesia". Jakarta.

Mokhatab, S dan W.A. Poe, 2012, "Handbook of Natural Gas Transmission and Processing". Elsivier Science B.V.

Walls, W.L. 1986. "Liquefied Petroleum Gases Handbook". National Fire Protection Association. 